\title{
Perancangan Aplikasi Sistem Pengendalian Stock Barang Pada UD. Makmur Jaya
}

\author{
Design Application Control System Stock goods in UD. \\ Makmur Jaya
}

\author{
Helmi Kurniawan \\ Universitas Potensi Utama; Jl. K.L Yos Sudarso KM 6,3 No. 3A Tanjung Mulia Medan \\ Jurusan Teknik Informatika, FTIK Universitas Potensi Utama, Medan \\ helmikurniawan77@gmail.com
}

\begin{abstract}
Abstrak
UD Makmur Jaya adalah perusahaan distributor penjualan makanan dan minuman ringan dengan berbagai merek dagang dalam jumlah besar maupun eceran yang dipasarkan di kota Medan. Dalam Melakukan Transaksi kepada pelanggan, UD Makmur Jaya mengalami suatu permasalahan dimana, bagian pemasaran dalam penjualan kepada pelanggan tidak mengatahui tersedia atau tidaknya barang yang dipesan oleh pelanggan. Hal ini terjadi disebabkan sistem pengendalian stok barang masih bersifat semi komputerisasi sehingga untuk mengetahui ada dan tidak adanya barang digudang tidak cepat terindentifikasi oleh bagian Pemasaran. Belum lagi, dalam pembuatan laporan khususnya pemasukan dan pengeluaran barang yang masih dalam pencatatan buku sehingga membutuhkan waktu yang lama dan tidak akurat. Solusi dari permasalahan tersebut adalah perlu dibangun suatu aplikasi pengendalian stock barang berbasis komputer dengan bahasa pemrograman VB.Net dan Database SQL Server, dimana aplikasi yang dihasilkan dapat mengontrol stock makanan dan minuman ringan yang ada digudang UD Makmur Jaya, dengan tujuan bagian pemasaran dapat mengetahui tersedianya barang yang ada digudang selain itu dapat meminimalkan pembatalan order dari pelanggan. Dengan adanya aplikasi pengendalian stock barang UD Makmur Jaya dapat disimpulkan bahwa bagian pemasaran dapat mengetahui informasi dan mengendalikan stock barang setiap saat, sehingga memberikan informasi yang akurat atas barang yang diminta dan barang yang tersedia digudang. untuk pengembangan lanjut aplikasi UD Makmur jaya dapat menambahkan sistem aplikasi keuangan perusahaan yaitu sistem akuntansi perusahaan.
\end{abstract}

Kata kunci-Aplikasi, Stock, Barang, Makanan dan Minuman

\begin{abstract}
UD Makmur Jaya is a sales distributor of food and soft drinks with various trademarks in bulk and retail marketed in the city of Medan. Transactions in options to customers, UD Makmur Jaya experiencing an issue where, the marketing department in sales to customers did not know the availability of the goods ordered by the customer. This happens due to the inventory control system is still semi computerized so as to determine the presence and absence of goods in warehouse are not quickly identified by the Marketing department. Not to mention, in making statements, especially revenue and expenditure items that are still in the record book so it takes a long time and inaccurate. The solution to these problems is necessary to build a stock of goods control applications based computer with VB.Net programming languages and database SQL Server, where the resulting application can control the stock of food and soft drinks that exist in warehouse UD Makmur Jaya, with the aim of marketing can be aware of the available existing goods warehouse but it can minimize the cancellation of orders from customers. With the application of control stock of goods UD Makmur Jaya can be concluded that the marketing department can find out information and controlling the stock of goods at any time, so as to provide accurate information on the requested items and goods warehouse. for the development of further applications UD Makmur Jaya can add the company's financial application system that the company's accounting system.
\end{abstract}

Keyword - Application, Stock, Goods, Food and Beverage 


\section{PENDAHULUAN}

Pada masa sekarang ini banyak terdapat perusahaan yang mengalami masalah dalam menangani transaksi penjualan di perusahaannya. Apalagi sekarang ini memasuki masa perdagangan bebas, di mana akan terdapat banyak perusahaan yang menjalin kerjasama yang akan mengakibatkan transaksi jual beli akan semakin banyak dan semakin kompleks permasalahannya. Oleh karena itu diperlukan suatu alat bantu yang bisa digunakan untuk mempercepat proses pengolahan data untuk menghasilkan informasi yang lebih akurat dan terpercaya sehingga bisa digunakan untuk pengambilan keputusan untuk pengembangan perusahaan di masa yang akan datang.

UD. Makmur Jaya adalah perusahaan distributor penjualan makanan dan minuman ringan dengan berbagai merek dagang yang dipasarkan di kota Medan dalam jumlah besar maupun eceran.Dalam melakukan pengendalian stocknya dilakukan berdasarkan ketentuan stock minimum dan stock maksimum berdasarkan nilai penjualan dan pembelian perusahaan.Sistem pengendalian stock makanan dan minuman ringan yang digunakan perusahaan pada saat ini masih menggunakan sistem semi komputerisasi dengan menggunakan Microsoft Excel untuk pengolahan datanya. Sistem yang digunakan ini dirasakan masih cukup lambat dalam penyajian laporan stock per jenis makanan ringan yang dimiliki perusahaan dan hasilnya sering tidak akurat, sehingga menimbulkan kekurangan stock dalam perusahaan pada saat penjualan meningkat serta stock yang berlebih ketika penjualan mengalami penurunan. Hal ini menimbulkan kekecewaan pelanggan karena jenis barang yang dipesan tidak ada, ataupun kerugian pada perusahaan karena menumpuknya stock di gudang yang rentan terhadap kerusakan atau mengalami kadaluarsa.

Banyaknya jenis makanan dan minuman ringan yang ditawarkan perusahaan kepada konsumen, maka diperlukan suatu sistem informasi yang bisa digunakan untuk mengontrol stock makanan ringan yang dimiliki perusahaan, sehingga bagian pemasaran dapat mengetahui persediaan makanan ringan yang telah terjual dan berapa yang harus dibeli, maka tidak pernah terjadi pembatalan order dari konsumen karena tidak adanya stock di gudang perusahaan. Selain itu, penggunaan sistem informasi berbasis komputer ini juga diharapkan bisa meningkatkan efisiensi pengolahan data, keakuratan data yang diproses, serta hasil pemprosesan data dapat diperoleh dengan cepat, terpercaya, serta memiliki tingkat ketelitian yang baik, sehingga memberikan informasi yang lengkap kepada pimpinan perusahaan.

Menurut Eric Tri Jatmika mengemukakan dalam penelitian yang berjudul “ Analisa dan Perancangan Sistem Informasi Persediaan Barang Pada Toko Sofia " menghasilkan penelitian berupa logical design, dimana desain tersebut dapat membantu dalam pengelolaan dan pengendalian terhadap persediaan barang. [1]

Menurut Rumanta mengemukanan dalam penelitian yang berjudul " Sistem Infomasi Pembelian dan Penjualan Pada Oka Putra Motor Pacitan" menghasilkan penelitian berupa sistem informasi penjualan dan pembelian barang kendaraan bermotor. [4]

Berdasarkan permasalahan yang dihadapi oleh UD Makmur Jaya dan hasil penelitian yang telah dilakukan oleh Eric Tri Jatmika dan Rumanta, maka penulis membangun suatu aplikasi pengendalian Stock Barang berbasis komputer dengan bahasa pemrograman VB.Net dan Database SQL Server [5], dimana aplikasi yang dihasilkan dapat mengontrol stock makanan dan minuman ringan yang ada digudang UD Makmur Jaya, dengan tujuan bagian pemasaran dapat mengetahui tersedianya barang yang ada digudang selain itu dapat meminimalkan pembatalan order dari pelanggan. Dengan adanya aplikasi pengendalian stock barang UD Makmur Jaya bagian pemasaran dapat mengetahui informasi dan mengendalikan stock barang setiap saat, sehingga memberikan informasi yang akurat atas barang yang diminta dan barang yang tersedia digudang. sehingga dapat membantu dalam kegiatan operasional perusahaan UD. Makmur Jaya. 


\section{METODE PENELITIAN}

Metode penelitian yang digunakan dalam penelitian ini yaitu metode pengumpulan data dan Pengembangan Sistem (System Development). Metode pengumpulan data yang digunakan penulis dalam penelitian ini adalah:

1. Penelitian Lapangan (Field Research)

Penelitian lapangan penulis lakukan untuk mendapatkan data yang akurat dalam membangun sistem ini. Adapun penelitan lapangan yang penulis lakukan mencakup:

a. Pengamatan (Observasi)

Pengamatan yang penulis lakukan merupakan pengamatan langsung pada UD. Makmur Jaya mengenai hal-hal yang berkaitan dengan pengendalian stock makanan ringan pada bagian pemasaran dan bagian gudang perusahaan.

b. Wawancara (Interview)

Wawancara yang penulis lakukan merupakan serangkaian tanya jawab secara langsung dengan kepala bagian pemasaran, untuk memperoleh data pengedalian stock makanan ringan yang digunakan perusahaan ini.

c. Sampling

Sampling yaitu dengan mengambil contoh dokumen yang berkaitan dengan topik yang dibahas dalam skripsi ini, seperti daftar nama makanan ringan, form penjualan dan form pembelian.

2. Penelitian Kepustakaan (Library Research)

Penelitian kepustakaan penulis lakukan untuk mendapatkan referensi dalam bentuk teori dari buku-buku yang berkaitan dengan masalah yang akan dibahas, yaitu mengenai sistem informasi pengendalian stock makanan ringan.

Pengembangan sistem merupakan langkah-langkah pembuatan sistem yang baru untuk menggantikan sistem yang lama secara keseluruhan atau memperbaiki sistem yang telah ada. Siklus hidup pengembangan sistem informasi Aplikasi pengendalian stockBarangmakanan dan minuman ringan ini terbagi enam fase, yaitu:

1. Perencanaan Sistem

Perencanaan sistem yang dilakukan dalam sistem informasi pengendalian stock makananringan ini mencakup tujuan pembangunan sistem yaitu untuk mempermudah perusahaan dalam melakukan pengendalian stock makanan ringan, serta perkiraan hardware, software, dan brainware yang dibutuhkan.

2. Analisis Sistem

Analisis sistem dilakukan untuk mencari kelebihan dan kelemahan sistem yang berjalan, serta memberikan solusi pemecahannya dengan mengajukan sistem usulan yaitu sistem informasi pengendalian stock makanan ringan menggunakan bahasa pemograman VB.Net dan SQL Server .

3. Desain atau Perancangan Sistem

Pada fase ini, analis sistem mulai melakukan perancangan sistem yang diusulkan secara global menggunakan data flow diagram dan disain sistem secara detail mencakup desain output, desain input, desain database, serta logika program menggunakan flowchart .

4. Evaluasi dan Seleksi Sistem

Tahap evaluasi dan seleksi sistem merupakan tahap untuk melakukan pemilihan perangkat keras dan perangkat lunak untuk sistem informasi yang dirancang yaitu sistem informasi pengendalian stock makanan ringan menggunakan bahasa pemograman VB.Net dan SQL Server .

5. Pengujian Sistem

Pada tahap ini dilakukan percobaan dan uji coba sistem untuk mengetahui apakah sistem sudah berjalan sesuai dengan tujuan pembuatan sistem, seperti mencari bug, memperbaiki 
bug, menguji keakuratan laporan yang dihasilkan, untuk menghasilkan laporan yang cepat dan akurat, serta memastikan program tersebut user friendly.

6. Implementasi dan Pemeliharaan Sistem

Perangkat lunak yang telah selesai diuji coba, kemudian diimplementasikan ke dalam sistem yang dimiliki oleh pemakai sistem, sehingga bisa diketahui kelebihan dan kekurangan sistem untuk pengembangan pada masa yang akan datang.

\section{HASIL DAN PEMBAHASAN}

Berdasarkan pengamatan yang dilakukan pada UD. Makmur Jaya dapat diketahui bahwa sistem yang digunakan masih menggunakan sistem semi komputerisasi sehingga dalam pengolahan data masih cukup lambat dan informasi yang dihasilkan sering tidak akurat.

Sedangkan sistem baru yang akan dibangun merupakan sebuah sistem informasi yang dirancang menggunakan Visual Basic.Net dan database menggunakan SQL Server. Sistem informasi pengendalian stock makanan ringan yang dibangun ini bisa digunakan oleh karyawan perusahaan untuk membuat laporan pengendalian stock makanan ringan yang ada pada perusahaan ini secara cepat dan akurat.

\section{Desain Sistem}

Untuk merancang proses-proses yang terjadi dalam sistem informasi yang penulis rancang, penulis menggunakan DFD (Data Flow Diagram) sebagai alat bantu perancangan proses. DFD yang penulis rancang terdiri dalam dua bagian yaitu diagram konteks dan DFD Level 0.

\section{Diagram Konteks}

Diagram konteks merupakan diagram yang penulis gunakan untuk menjelaskan secara umum proses-proses yang terjadi pada sistem pengendalianstokmakananyang dirancang. Adapun bentuk diagram konteks dari sistem informasi yang dirancang ini seperti terlihat pada Gambar 1.

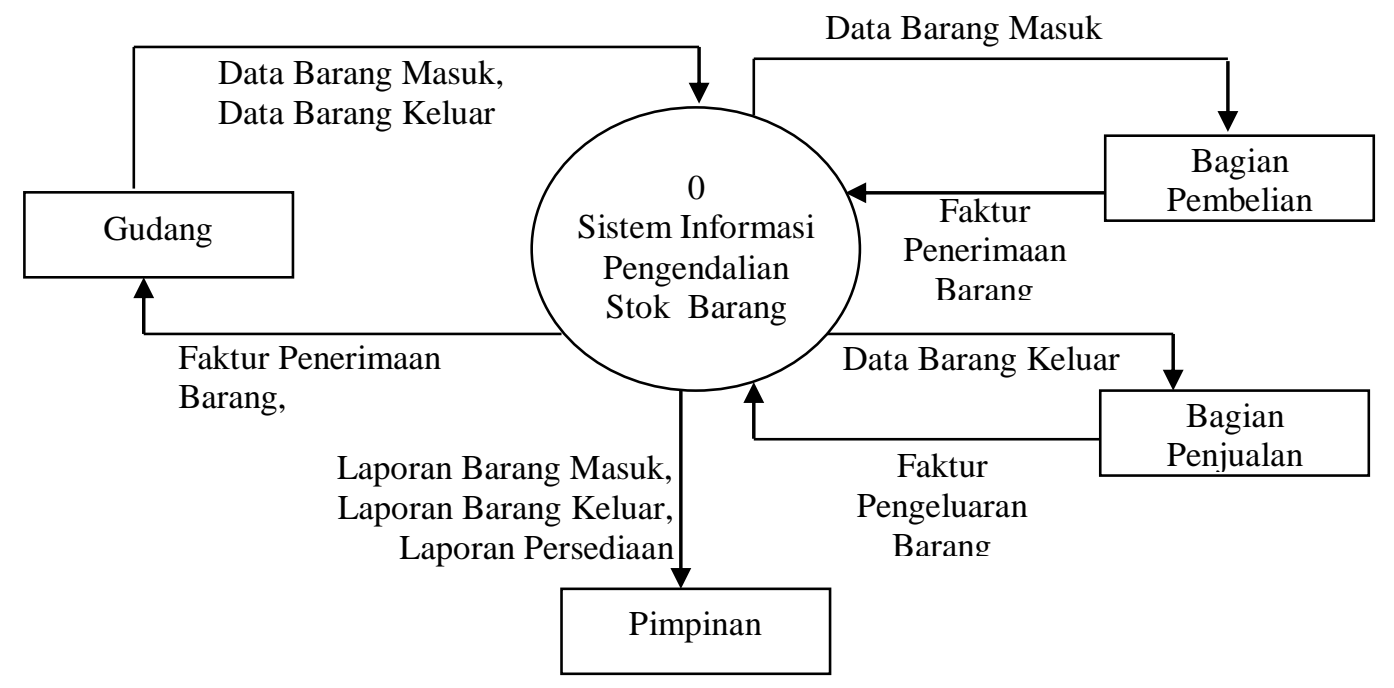

Gambar 1. Diagram Konteks Sistem

Dalam sistem yang sedang berjalan pada UD. Makmur Jaya, proses pencatatan persediaan barang yang digunakan ini adalah sebagai berikut : 
1. Bagian Gudang mencatat setiap barang masuk hasil pembelian barang yang dilakukan bagian Pembelian dan mengeluarkan faktur Barang Masuk Gudang

2. Setiap ada permintaan pengeluaran barang dari bagian Penjualan, bagian Gudang melakukan pengecekan terhadap stok barang yang diinginkan dan mengeluarkan faktur Barang Keluar Gudang.

3. Bagian Gudang melakukan rekap terhadap setiap faktur Barang Masuk Gudang dan faktur Barang Keluar Gudang dalam bentuk laporan Barang Masuk dan laporan Barang Keluar.

4. Laporan ini kemudian diserahkan kepada pimpinan. Pimpinan mengecek laporan yang diterima dari bagian Gudang dan menandatangani laporan tersebut.

\section{Data Flow Diagram (DFD) Level 0}

Sedangkan DFD Level 0 dalam perancangan sistem ini dapat dilihat pada Gambar 2.

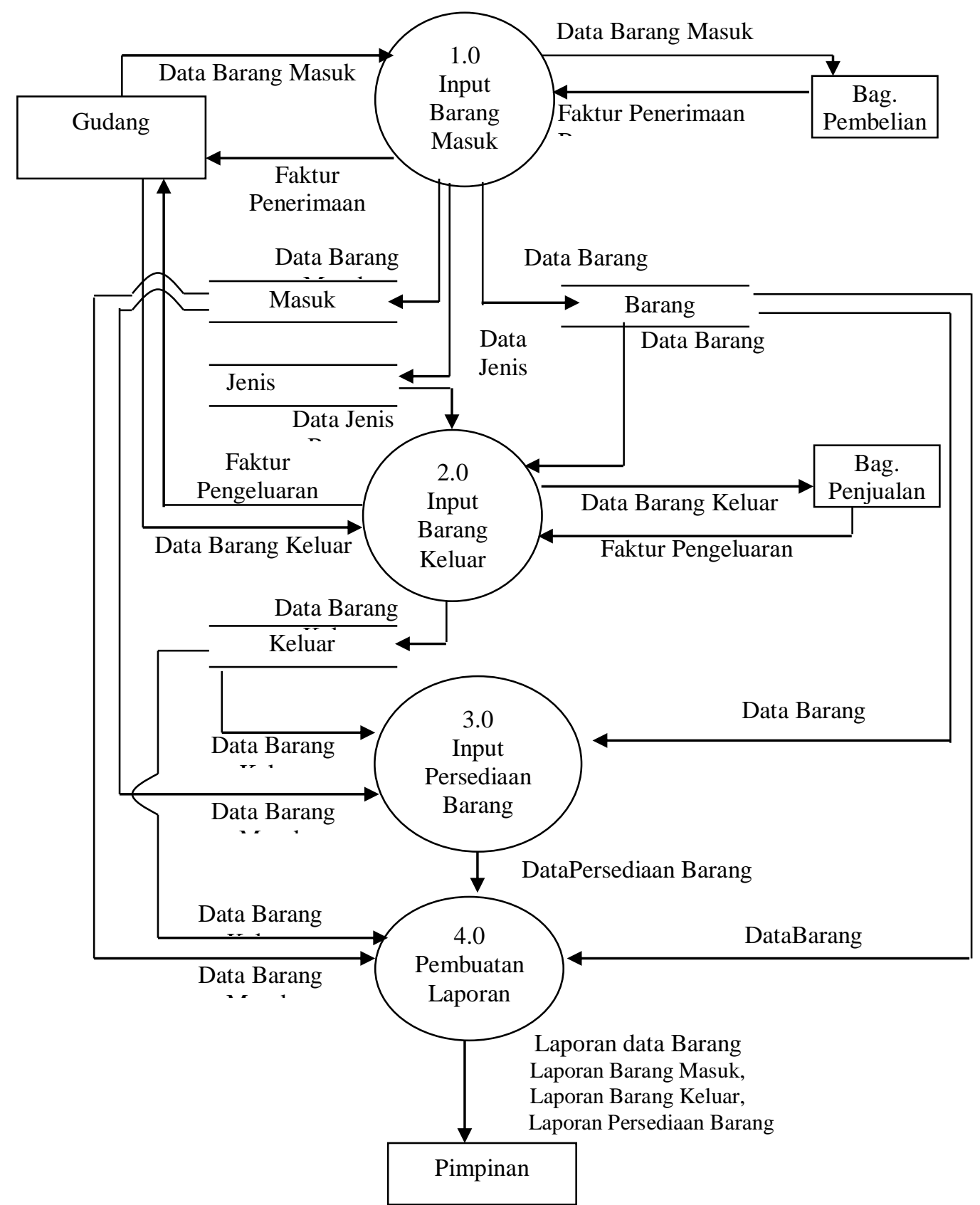

Gambar 2. Data Flow Diagram (DFD) Level 0 


\section{Hasil}

Setelah membuat perancangan sistem, maka penulis akan menampilkan hasil dari sistem yang dibuat oleh penulis dalam bentuk tampilan eksekusi program. Adapun tampilan tersebut dapat dilihat sebagai berikut:

1. Form Sub Menu File Master

Sub menu file master dirancang untuk menampilkan menu Data Jenis Barang, Data Barang, Data Barang Masuk, Data Barang Keluar, Persediaan dan keluar. Tampilan sub menu data File Master dapat dilihat pada gambar 3.:

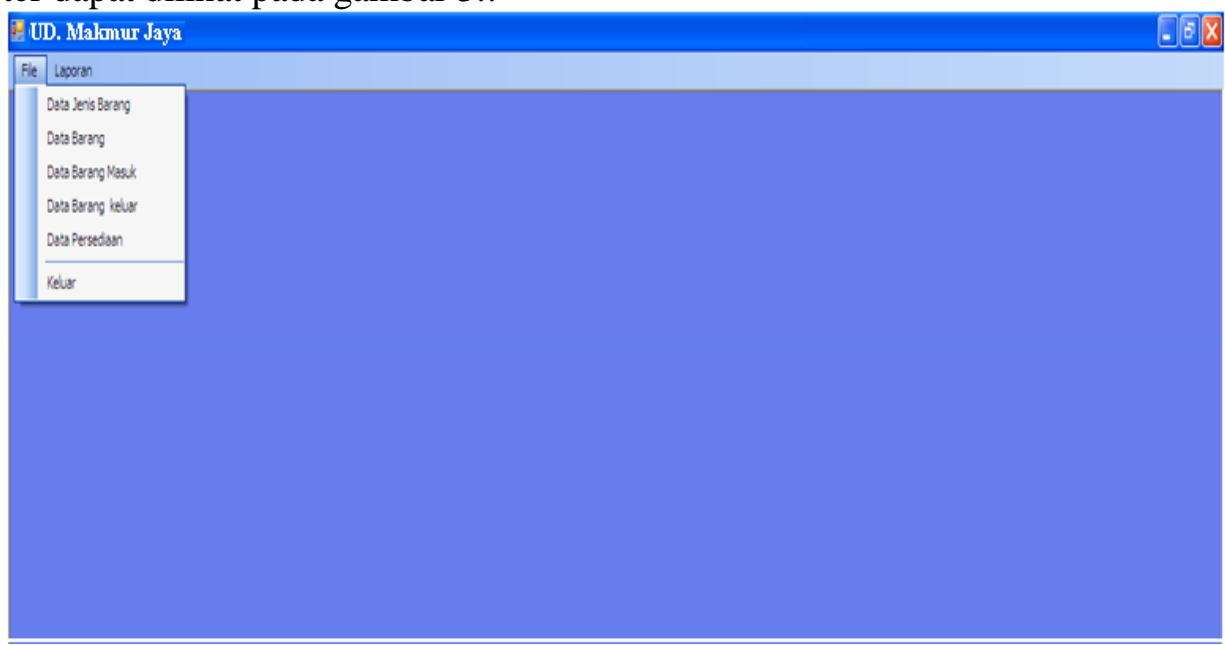

Gambar 3. Tampilan Form Sub Menu File Master

2. Tampilan Form Data Jenis Barang

Tampilan form data jenis barang digunakan untuk memasukkan kode jenis barang dan jenis barang apa saja yang terdapat pada datajenis barang. Tampilan menu data jenis barang dapat dilihat pada gambar 4:

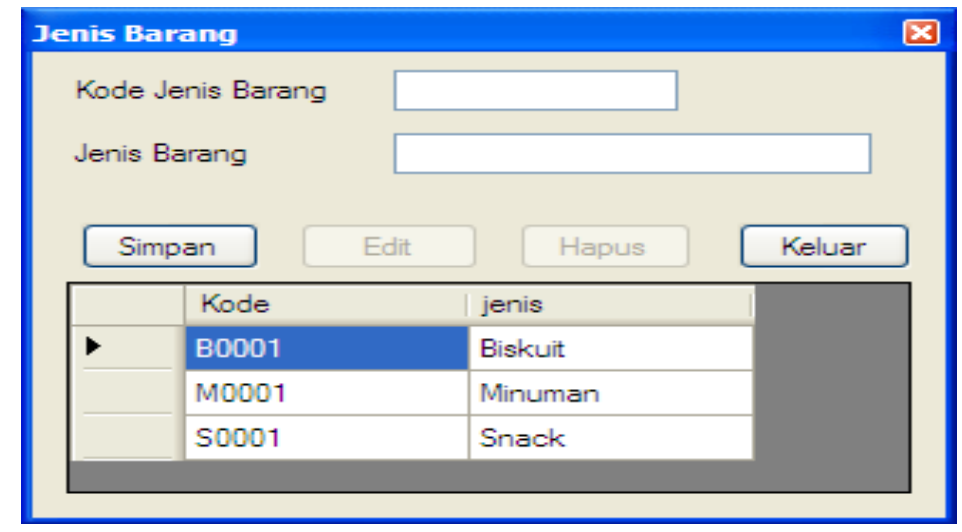

Gambar 4. Tampilan Form Jenis Barang

3. Tampilan Form Data Barang

Tampilan Form data barang digunakan untuk memasukkan data-data barang yang tersedia di UD. Makmur Jaya. Tampilan form data barang dapat dilihat pada gambar 5. 


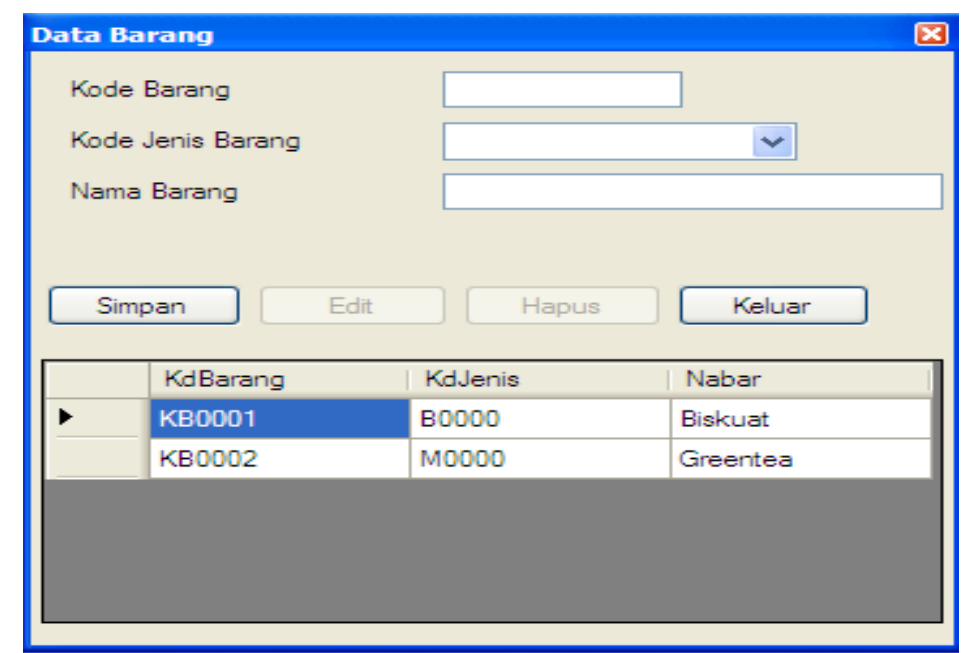

Gambar 5. Tampilan Form Data Barang

4. Tampilan Form Data Barang Masuk

Tampilan form data barang masuk digunakan untuk memasukkan data-data barang yang masuk ke gudang. Tampilan form data barang masuk dapat dilihat pada gambar 6 :

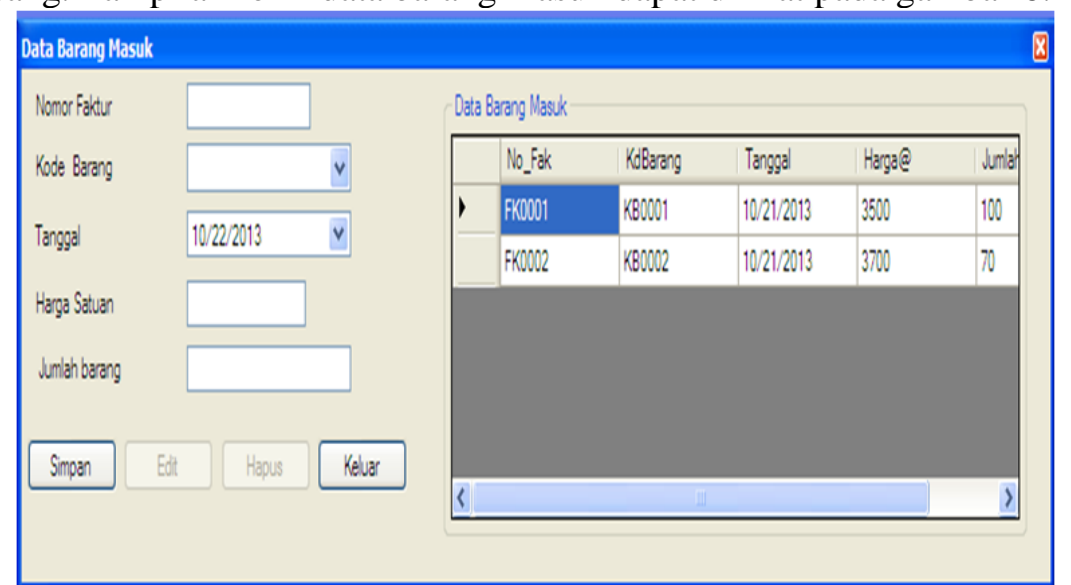

Gambar 6. Tampilan Form Data Barang Masuk

5. Tampilan Form Data Barang Keluar

Tampilan Form Data barang keluar digunakan untuk mendata barang-barang yang keluar dari gudang. Tampilan pengeluaran barang dapat dilihat pada gambar 7 berikut :

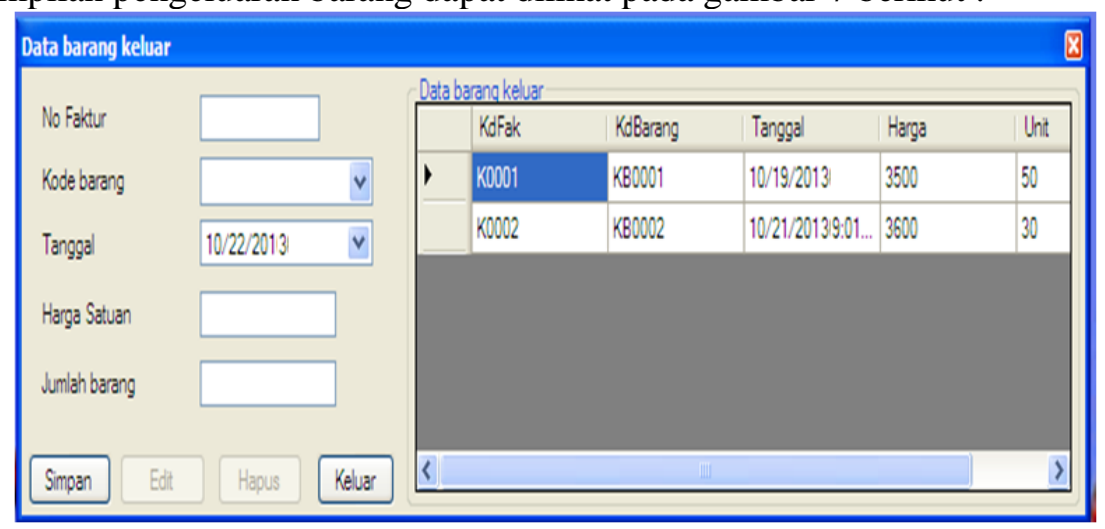

Gambar 7. Tampilan Form Data Barang Keluar

6. Tampilan Form Data Persediaan 
Tampilan Form Data persediaan digunakan untuk mendata barang-barang yang ada di gudang. Tampilan persediaan barang dapat dilihat pada gambar 8 berikut :

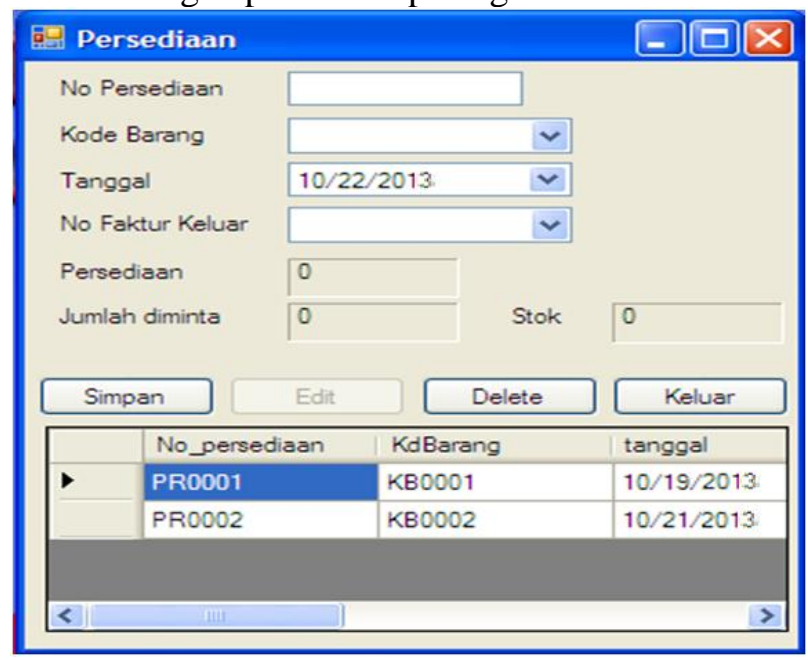

Gambar 8 Tampilan Form Data Persediaan

7. Tampilan Sub Menu Laporan

Sub menu laporan dirancang untuk menampilkan laporan barang, laporan barang masuk, laporan barang keluar, laporan persediaan barang seperti pada gambar 9 .

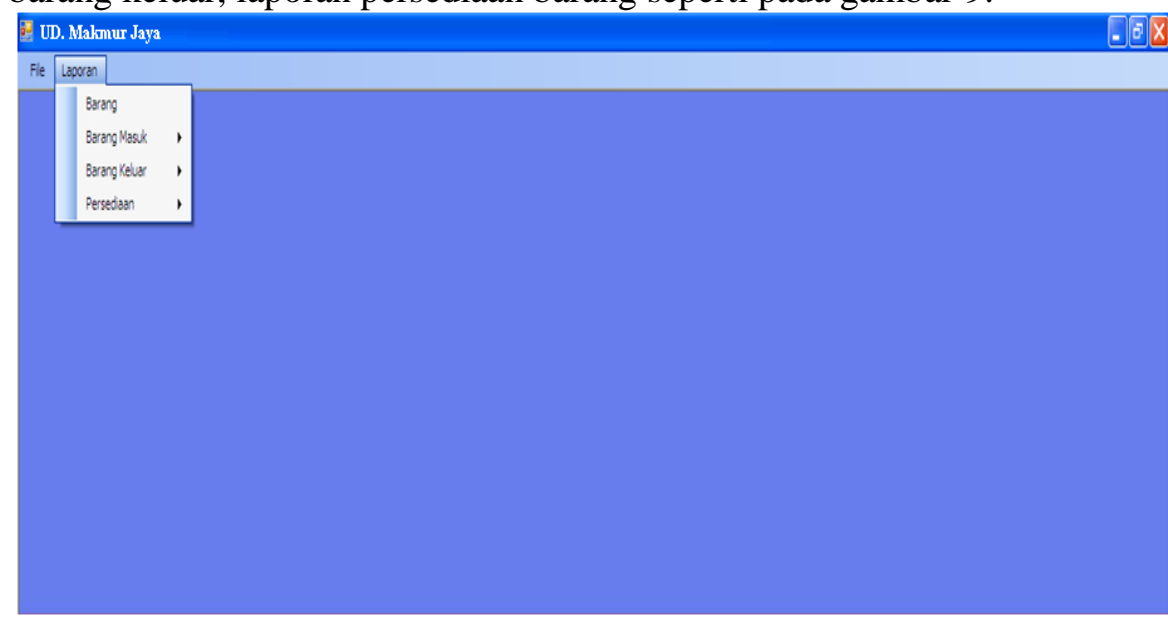

Gambar 9. Tampilan Sup Menu Laporan

8. Tampilan Laporan Data Barang

Tampilan laporan barang digunakan untuk membuat laporan data barang yang ada digudang Seperti terlihat pada gambar 10 .

UD. MAKMUR JAYA

Laporan Barang

\begin{tabular}{|c|l|l|}
\hline $\begin{array}{c}\text { Kode } \\
\text { Barang }\end{array}$ & \multicolumn{1}{|c|}{$\begin{array}{c}\text { Kode } \\
\text { Jenis Barang }\end{array}$} & \multicolumn{1}{|c|}{$\begin{array}{c}\text { Nama } \\
\text { Barang }\end{array}$} \\
\hline KB0001 & B0000 & Biskuat \\
KB0002 & M0000 & Greentea \\
\hline
\end{tabular}

Medan 22 October, 2013

Gambar 10. Laporan Data Barang 
9. Tampilan Laporan Data Barang Masuk Perhari

Tampilan laporan Data barang Masuk Perhari digunakan untuk membuat laporan data barang yang masuk ke gudang dalam satu hariseperti terlihat pada gambar 11 .

\section{UD. MAKMUR JAYA}

Laporan Masuk Tanggal $21 \quad$ October 2013

\begin{tabular}{|c|l|c|c|c|c|}
\hline $\begin{array}{c}\text { No } \\
\text { Faktur }\end{array}$ & \multicolumn{1}{|c|}{$\begin{array}{c}\text { Nama } \\
\text { Barang }\end{array}$} & $\begin{array}{c}\text { Kode } \\
\text { Barang }\end{array}$ & \multicolumn{1}{|c|}{ Tanggal } & $\begin{array}{c}\text { Harga } \\
\text { Satuan }\end{array}$ & $\begin{array}{c}\text { Jumlah } \\
\text { Barang }\end{array}$ \\
\hline FK0001 & Biskuat & KB0001 & $10 / 21 / 2013$ & 3,500 & 100 \\
FK0002 & Greentea & KB0002 & 10212013 & 3,700 & 100 \\
\hline
\end{tabular}

Medan,22 October, 2013

Gambar 11. Laporan Data Barang Masuk Perhari

10. Tampilan Laporan Data Barang Masuk Perbulan

Tampilan laporan Data barang Masuk Perbulan digunakan untuk membuat laporan data barang yang masuk ke gudang dalam satu bulan seperti terlihat pada gambar 12 .

\begin{tabular}{|c|c|c|c|c|c|}
\hline \multicolumn{6}{|c|}{$\begin{array}{l}\text { UD. MAKMUR JAYA } \\
\text { Laporan Barang Masuk Bulan October }\end{array}$} \\
\hline $\begin{array}{l}\text { Nomor } \\
\text { Faktur }\end{array}$ & Nama Barang & Kode Barang & $\begin{array}{c}\text { Tanggal } \\
\text { Masuk }\end{array}$ & $\begin{array}{l}\text { Harga } \\
\text { Barang }\end{array}$ & $\begin{array}{l}\text { Jumlah } \\
\text { Barang }\end{array}$ \\
\hline FK0001 & Biskuat & KB0001 & $10 / 21 / 2013$ & 3,500 & 100 \\
\hline FK0002 & Greentea & $\mathrm{KB} 0002$ & $10 / 21 / 2013$ & 3700 & 100 \\
\hline
\end{tabular}

Medan, 22 October, 2013

Gambar 12. Laporan Data Barang Masuk Perbulan

11. Tampilan Laporan Data Barang Keluar Perhari

Tampilan laporan Data barang keluar Perhari digunakan untuk membuat laporan data barang yang keluar digudang dalam satu hari seperti terlihat pada gambar 13 .

UD. MAKMUR JAYA

Laporan Keluar Tanggal 21 October 2013.

\begin{tabular}{|c|l|c|c|c|c|}
\hline $\begin{array}{c}\text { No } \\
\text { Faktur }\end{array}$ & $\begin{array}{c}\text { Nama } \\
\text { Barang }\end{array}$ & $\begin{array}{c}\text { Kode } \\
\text { Barang }\end{array}$ & Tanggal & $\begin{array}{c}\text { Harga } \\
\text { Satuan }\end{array}$ & $\begin{array}{c}\text { Jumlah } \\
\text { Barang }\end{array}$ \\
\hline K0002 & Greentea & KB0002 & $10 / 21 / 2013$ & 3.600 & 30 \\
\hline
\end{tabular}

Medan,22 October, 2013.

Gambar 13. Laporan Data Barang Keluar Perhari 
12. Tampilan Laporan Data Barang Keluar Perbulan

Tampilan laporan Data barang keluar Perbulan digunakan untuk membuat laporan data barang yang keluar digudang gudang dalam satu bulan Seperti terlihat pada gambar 14 .

UD. MAKMUR JAYA

Laporan Barang Keluar Bulan October 2013

\begin{tabular}{|l|l|c|c|r|r|}
\hline $\begin{array}{c}\text { Nomor } \\
\text { Faktur }\end{array}$ & \multicolumn{1}{|c|}{ Nama Barang } & $\begin{array}{c}\text { Kode } \\
\text { Barang }\end{array}$ & $\begin{array}{c}\text { Tanggal } \\
\text { Keluar }\end{array}$ & $\begin{array}{c}\text { Harga } \\
\text { Barang }\end{array}$ & $\begin{array}{c}\text { Jumlah } \\
\text { Barang }\end{array}$ \\
\hline K0001 & Biskuat & KB0001 & $10 / 19 / 2013$ & 3,500 & 50 \\
K0002 & Greentea & KB0002 & $10 / 21 / 2013$ & 3,600 & 30 \\
\hline
\end{tabular}

Gambar 14. Laporan Data Barang keluar Perbulan

13. Tampilan Laporan Persediaan Barang

Tampilan laporan persediaan barang digunakan untuk membuat laporan data persediaan barang digudangseperti terlihat pada gambar 15 .

UD. MAKMUR JAYA

Laporan Seluruh Persediaan

\begin{tabular}{|c|c|c|c|c|c|}
\hline $\begin{array}{c}\text { Kode } \\
\text { Barang }\end{array}$ & Tanggal & $\begin{array}{c}\text { Kode } \\
\text { Faktur }\end{array}$ & $\begin{array}{c}\text { Jumlah } \\
\text { diterima }\end{array}$ & $\begin{array}{c}\text { Jumlah } \\
\text { Diminta }\end{array}$ & $\begin{array}{c}\text { Stok } \\
\text { Barang }\end{array}$ \\
\hline KB0001 & $10 / 19 / 2013$ & K0001 & 100 & 50 & 50 \\
KB0002 & $10 / 21 / 2013$ & K0002 & 100 & 30 & 70 \\
\hline
\end{tabular}

Medan 22 October, 2013

Gambar 15. Laporan Persediaan Barang

\section{Pembahasan}

Tahap terakhir dalam pembahasan sistem informasi yang di buat adalah pengujian sistem informasi bengkel mobil yang telah di rancang. Pengujian sistem informasi ini dilakukan untuk menguji dan mengetahui apakah sistem aplikasi telah berjalan dengan baik dan benar. Sistem ini menggunakan satu jenis pengujian, yaitu tabel black box test.

Hasil uji perangkat dan sistem ini dapat dilihat pada tabel berikut :

Tabel 1. Daftar Pertanyaan Black Box Test

\begin{tabular}{llll}
\hline No & \multicolumn{1}{c}{ Pertanyaan } & $\mathrm{Y}$ & $\mathrm{T}$ \\
\hline 1. & $\begin{array}{l}\text { Apakah koneksi system yang dirancang dengan system operasi berjalan } \\
\text { dengan baik? }\end{array}$ & $\sqrt{ }$ & \\
\hline 2. & Apakah aplikasi interface yang dibangun mudah dimengerti pengguna? & $\sqrt{ }$ \\
\hline 3. & $\begin{array}{l}\text { Apakah proses pengoperasian program aplikasi dan sistem operasi berjalan } \\
\text { dengan benar? }\end{array}$ & $\sqrt{ }$ \\
\hline 4. & $\begin{array}{l}\text { Apakah output informasi dari aplikasi sudah sesuai dengan aturan yang } \\
\text { diacu? }\end{array}$ & $\sqrt{ }$ \\
\hline 5. & Apakah tampilan aplikasi interface yang dibangun sangat menarik? & $\sqrt{ }$ \\
\hline
\end{tabular}


Berdasarkan hasil dari tabel diatas, didapat persentase penilaian terhadap aplikasi yaitu: $5 / 5 \times 100 \%=100 \%$, Tidak $=0 / 5 \times 100 \%=0 \%$. Dari hasil uji persentase tersebut dapat ditarik kesimpulan bahwa data dan informasi yang disampaikan sudah sesuai dengan aturan yang ditetapkan sekaligus mencerminkan sistem yang dibangun sudah baik. Perancangan Aplikasi Pengendaliaan Stock Barang Pada UD. Makmur Jaya ini dapat diakses pengguna sehingga informasi yang dibutuhkan pengguna dapat disajikan secara cepat dan akurat. Dan Aplikasi yang dihasilkan dapat menyajikan informasi barang yang tersedia, barang yang diminta dan stok barang.

\section{KESIMPULAN}

Setelah dilakukan uji coba dan evaluasi terhadap Aplikasi Pengendaliaan Stock Barang makanan dan minuman ringan yang telah berhasil dibangun, maka dapat ditarik kesimpulan sebagai berikut:

1. Aplikasi pengendalian Stock barang dapat mempermudah dalam pengolahan data persediaan, perhitungan penjualan dan pembelian dan dapat memperkecil kesalahan.

2. Dengan menggunakan Aplikasi yang dibangun dapat mengurangi kendala yang ada di UD. Makmur Jaya jika terjadi kesalahan dan informasi tentang stock persediaan makanan dan minuman ringan tersedia setiap saat jika dibutuhkan.

3. Aplikasi yang dibangun ini dapat memberikan informasi data barang, data barang masuk, data barang keluar dan persediaan barang yang terdiri dari barang yang diterima, barang yang diminta dan stock barang

\section{SARAN}

Adapun saran yang dapat penulis berikan untuk pengembangan penelitan lebih lanjut adalah sebagai berikut:

1. Untuk pengembangan aplikasi sebaiknya aplikasi sudah berbasis online sistem agar dapat diakses dimana saja dan kapan saja.

2. Sebaiknya sistem pengendalian stock barang menerapkan suatu metode control srock.

\section{UCAPAN TERIMA KASIH}

Penulis mengucapkan terima kasih kepada Pimpinan dan Yayasan Universitas Potensi Utama yang telah memberi dukungan financial terhadap penelitian ini.

\section{DAFTAR PUSTAKA}

[1 ]. Eric TriJatmika, Magmaz Lestira Oktaroza, Diamonalisa, 2015, Analisa dan Perancangan Sistem Informasi Persediaan Barang di Toko Sofia, Prosiding Penelitian SPeSIA, Bandung

[2 ]. Agus Ristono, 2009, Manajemen Persediaan, Graha Ilmu, Yogyakarta.

[3 ]. Laudon, Kenneth C., Jane P. Laudon 2011, Sistem Informasi ManajemenMengelola Perusahaan Digital Buku 1 Edisi 10, Salemba Empat, Jakarta.

[4 ]. Rumanta, 2013,Sistem Informasi Pembelian Dan Penjualan Pada Oka Putra Motor Pacitan, Speed Journal -Indonesian Jurnal on Computer Science - Vol 10 No 3, ISSN 1979 - 9330, speed.unsa.ac.id

[5 ]. Wahana Komputer 2010, SQL Server2008 Express, Andi Offset, Yogyakatra. 